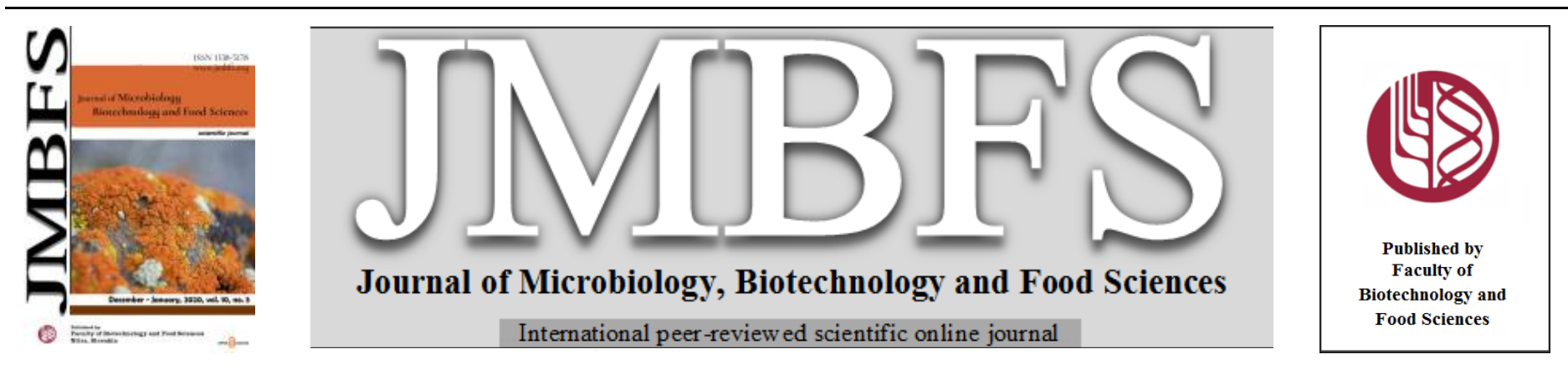

\title{
ANTIBACTERIAL EFFECT OF ARGENTINIAN POLLENS AND HONEYS
}

\author{
Tejerina Marcos $R . *^{*}$, Cabana María J. , Sánchez Carina A. ${ }^{2}$, Benitez-Ahrendts Marcelo $R^{l}$. \\ Address(es): Dr. Marcos Raúl Tejerina \\ ${ }^{1}$ Cátedra de Microbiología, Sanidad Apícola y Meliponícola; Facultad de Ciencias Agrarias, Universidad Nacional de Jujuy, Alberdi 47,4600 Jujuy, Argentina. \\ ${ }^{2}$ Cátedra de Ecología General y Laboratorio de Palinología; Facultad de Ciencias Agrarias, Universidad Nacional de Jujuy, Alberdi 47,4600 Jujuy, Argentina.
}

*Corresponding author: tejerina.marcos@yahoo.com

doi: $10.15414 /$ jmbfs.2020.10.3.381-384

\section{ARTICLE INFO}

Received 20. 5. 2020

Revised 13. 7. 2020

Accepted 14. 7. 2020

Published 1. 12. 2020

Regular article

open $\odot$ access

\begin{abstract}
Honey and pollen are considered functional foods, due to their multiple properties since they have a great diversity of active principles according to their botanical origin. The aim of this work was to analyze the antimicrobial effect of pollens and honeys from different origins of Argentina against the antibiotic resistant Shigella flexneri, enteropathogenic Escherichia coli and Salmonella typhi. Honey samples showed a significant effect over the inhibition of them, being higher in Salmonella. Pollen inhibited Shigella and Salmonella and showed no effect on Escherichia. The concentration of total phenols was higher in pollen than in honey. The highest value observed in honey was $7.48 \mathrm{mg} / \mathrm{L}$ in a sample from Entre Ríos, and it was $8.66 \mathrm{mg} / \mathrm{L}$ in pollen from Neuquén.
\end{abstract}

Keywords: Shigella flexneri, enteropathogenic Escherichia coli, Salmonella typhi, honey, pollen, phenols

\section{INTRODUCTION}

Honey and pollen bee are products stored by the hive and they are considered as functional food (Libonatti et al., 2014). Its production in Argentina has increased in recent years. Several compounds contribute significantly to the antibacterial properties of honey, such as hydrogen peroxide, methylglyoxal, melanoidins, oxidative stress and hydroxyl radicals, through a multimodal action mechanism (Kwakman et al 2010). Brudzynski and Sjaarda (2015) demonstrated in honey a glycoprotein that inhibits the growth of Escherichia coli and Bacillus subtilis through cell lysis and/or spheroplast formation.

The pollen collected by bees is known as antibacterial, antifungal and immunomodulatory. It is composed mainly of polysaccharides, simple sugars, lipids, amino acids, proteins and other side compounds, such as flavonoids, vitamins, minerals and pigments such as carotenoid. Its chemical compositions, depends on its floral origin (Cabrera and Montenegro, 2013).

Natural compounds against antibiotic resistant microorganisms are sought because the bacteria that accumulate multiple antibiotic resistances are able to spread in different geographical regions (Rosenblatt-Farrell, 2009).

The species of Salmonella and Shigella are one of the major causes of diarrhea and dysentery worldwide, responsible for significant morbidity and mortality in developing countries (Della Gaspera et al., 2015). Although a variety of antibiotics have been effective in treating shigellosis and salmonellosis, the options are increasingly limited due to drug resistance (Saurabh et al., 2015). Enteropathogenic E. coli remains the most common cause of infant morbidity. The diarrheagenic strains can be transmitted through the fecal-oral route by ingesting food or water contaminated (Adefisoye and Okoh, 2016). An increase in resistance has been observed in the last six decades after the introduction of new antibiotics (De Toro et al., 2014)

The aim of this study was to analyze the antimicrobial effect of pollens and honeys from different origins of Argentina against enteropathogenic Escherichia coli, Salmonella typhi, and Shigella flexneri, which are antibiotic resistant. Also, know the phenol concentrations in honeys and pollen and their relationship with the botanical origin.

\section{MATERIAL AND METHODS}

\section{Samples}

Honey samples were obtained from the provinces of Misiones, Chaco, Entre Rios, Corrientes and Jujuy and pollen from the provinces of Buenos Aires, Santa Fe, Entre Rios, Neuquén, Tucumán, Misiones, Santiago del Estero and Jujuy. Samples were collected in sterile containers and kept at room temperature.

\section{Microorganisms}

Shigella flexneri, Salmonella typhi, and enteropathogenic E. coli provided by Jujuy Children Hospital were identified by biochemical tests. The strains were transferred weekly to Luria-Bertani or selenite media and incubated for $24 \mathrm{~h}$ at $37^{\circ} \mathrm{C}$ ). They were stored at $4^{\circ} \mathrm{C}$ in $20 \%$ glycerol medium (Ruíz et al., 2018).

The antibiograms were performed by the disk-plate technique (Bauer, Kirby $\boldsymbol{e}$ al., 1966). The antibiotics were erythromycin, vancomycin, tetracycline, rifampicin, cephalotin, penicillin, neomycin, gentamicin, kanamycin, and streptomycin.

The resistance tests were made using $200 \mu \mathrm{L}$ of fresh culture $\left(10^{5} \mathrm{cfu} / \mathrm{mL}\right)$ onto Mueller Hinton agar, against $20 \mu \mathrm{L}$ of honey or pollen suspension (1: 1) in sterile water. They were incubated at $37^{\circ} \mathrm{C}$ up to stationary growth phase. The inhibition halos were measured after 24 hours in millimeters.

\section{Determination of phenols}

One $\mathrm{mL}$ honey or $1 \mathrm{~g}$ of pollen was dissolved in $50 \mathrm{~mL}$ of distilled water and 0.5 $\mathrm{mL}$ of the solution was added to $0.75 \mathrm{~mL}$ Folin-Ciocalteau reagent $1 \mathrm{~N}$ (Töpfer, 2018). It was settled for about 5 minutes and $0.75 \mathrm{~mL}$ of sodium carbonate $20 \%$ was added. It was shaken and allowed to settle for $2 \mathrm{~h}$ and reading at $760 \mathrm{~nm}$. Measurements were performed by duplicate.

\section{Botanical origin of honeys and pollen}

Qualitative analysis of the honey sample was carried out following the method described by Louveaux et al. (1970) using the acetolysis method (Erdtman, 1960). The pollen samples were disintegrated and homogenized with mortar, taking $0.5 \mathrm{~g}$ of the total for further acetolysis treatment (Erdtman, 1960). Pollen sediment was mounted into glycerin and sealed with paraffin. Observations were made with a light microscope. To determine the frequency classes, 600 pollen grains were counted (Louveaux et al., 1970). Pollen types were identified according the palynotheca of the Facultad de Ciencias Agrarias, UNJu (PALJUA), and palynological atlas. The classes are: predominant pollen ' $\mathrm{D}$ ' ( $>$ $45 \%)$, secondary pollen ' $\mathrm{S}$ ' $(16-45 \%)$, important minor pollen ' $\mathrm{M}$ ' (3-15\%), trace pollen ' $\mathrm{T}$ ' $(<3 \%)$ (Louveaux et al., 1970).

\section{Analysis of results}

Statistical analysis of the results will be performed by ANOVA test and Tukey comparison with 0.05 probability of committing Type I error, using a InfoStat statistical package (Di Rienzo et al., 2008). A canonical correspondence analysis 
(CCA) was performed to establish the relationship between the botanical origen, concentration of phenol and measuring inhibition halos using CANOCO 4.5 software package (Leps and Smilauer, 2003).

\section{RESULTS}

All honey samples showed a significant effect $(\mathrm{p}=0.04)$ in the inhibition of $S$ flexneri, E. coli, and S. typhi strains, being higher in the latter (Table 1). Pollen inhibited Shigella and Salmonella, but not the Escherichia strain (Table 2).

Table 1 Honeys against pathogen strains.

\begin{tabular}{lcccc}
\hline \multirow{2}{*}{ Origin } & \multicolumn{4}{c}{ Inhibition halos (mm) } \\
\cline { 2 - 5 } & $\begin{array}{c}\text { Total } \\
\text { phenols } \\
\mathrm{mg} / \mathrm{L}\end{array}$ & S. typhi & S. flexneri & E. coli \\
\hline Entre Ríos & 6.38 & $37 \pm 1.41$ & $40.75 \pm 1.75$ & $13.25 \pm 2.75$ \\
\hline Misiones & 3.35 & $44.5 \pm 0.71$ & $41 \pm 9.27$ & $36.5 \pm 2.12$ \\
\hline Jujuy (San Salvador) & 5.28 & $30.5 \pm 0.71$ & $27.5 \pm 2.12$ & $25 \pm 1.41$ \\
\hline Chaco & 4.37 & 45 & $36.25 \pm 5.06$ & $34.25 \pm 4,11$ \\
\hline Jujuy (Palpala) & 5.4 & $41.5 \pm 4.95$ & 23 & $34 \pm 3.46$ \\
\hline Corrientes & 4.72 & $39.5 \pm 0.71$ & $49.5 \pm 0.71$ & $34 \pm 4.62$ \\
\hline Jujuy(Palpala Orgánica) & 6.42 & $39.5 \pm 0.58$ & $28.5 \pm 3.54$ & $34 \pm 8.13$ \\
\hline Jujuy (Tilquiza) & 6.12 & $41.75 \pm 0.5$ & $27 \pm 1.41$ & $28.8 \pm 2.3$ \\
\hline Jujuy (Santa Bárbara) & 5.87 & $32.5 \pm 0.58$ & $32.75 \pm 1.71$ & $32 \pm 0.83$ \\
\hline
\end{tabular}

Table 2 Pollen grains against pathogens strains.

\begin{tabular}{lcccc}
\hline \multirow{2}{*}{ Origin } & \multicolumn{4}{c}{ Inhibition halos (mm) } \\
\cline { 2 - 5 } & $\begin{array}{c}\text { Total } \\
\text { Phenols } \\
\mathrm{mg} / \mathrm{L}\end{array}$ & S. typhi & S. flexneri & E. coli \\
\hline Buenos Aires & 4.58 & $31.5 \pm 2.12$ & $28 \pm 1$ & - \\
\hline Santa Fe & 4.34 & $35.5 \pm 4.95$ & $25.75 \pm 2.87$ & - \\
\hline Entre Ríos & 7.48 & 40 & $31 \pm 2.83$ & - \\
\hline Neuquén & 8.66 & $37 \pm 1.41$ & $26.75 \pm 1.26$ & - \\
\hline Tucumán & 5.78 & $32.25 \pm 0.96$ & $16 \pm 5.66$ & - \\
\hline Misiones & 5.98 & $29 \pm 1.41$ & $24.25 \pm 2.87$ & - \\
\hline Santiago del Estero & 4.61 & 26 & $12.5 \pm 0.71$ & - \\
\hline Jujuy (San Salvador) & 8.32 & $27.75 \pm 1.5$ & $18.75 \pm 0.96$ & - \\
\hline
\end{tabular}

The concentration of total phenols was different according to the regions, being higher in pollen than in honey, showing significant difference between them $(\mathrm{p}=0.02)$ (Tables 1 and 2). The highest values observed were $7.48 \mathrm{mg} / \mathrm{L}$ in honey from Entre Rios and $8.66 \mathrm{mg} / \mathrm{L}$ in pollen from Neuquén. E. coli was the most influenced by phenols content of honey.

Antibiotics tested were found to have lower inhibitory effect in relation to the samples of honey and pollen $(\mathrm{p}=0.001)$ (Table 3$)$. Honeys from Corrientes and Entre Rios showed a greater inhibitory effect than antibiotics.

Table 3 Antibiograms

\begin{tabular}{lccc}
\hline \multirow{2}{*}{ Antibiotics } & \multicolumn{3}{c}{ Inhibition halos $(\mathrm{mm})$} \\
\cline { 2 - 4 } & S. typhi & S. flexneri & E. coli \\
\hline Erythromycin $(60 \mu \mathrm{g})$ & 9 & 23 & - \\
\hline Vancomycin $(30 \mu \mathrm{g})$ & 21 & 21 & - \\
\hline Tetracyclin $(30 \mu \mathrm{g})$ & 15 & 36 & - \\
\hline Rifampicin $(15 \mu \mathrm{g})$ & 13 & 20 & - \\
\hline Cephalotin $(30 \mu \mathrm{g})$ & - & - & - \\
\hline Penicillin $(10 \mathrm{U})$ & - & 16 & - \\
\hline Neomycin $(30 \mu \mathrm{g})$ & 10 & 9 & 16 \\
\hline Gentamicin $(10 \mu \mathrm{g})$ & 9 & 10 & 14 \\
\hline Kanamycin $(120 \mu \mathrm{g})$ & - & - & 22 \\
\hline Streptomycin $(300 \mu \mathrm{g})$ & 14 & - & 25 \\
\hline
\end{tabular}

\section{Botanical origen of honeys}

From the 9 honey samples analyzed, 56 pollen types were identified belonging to 34 botanical families. Fabaceae presented eight pollen types, Asteraceae seven, Euphorbiaceae and Rhamnaceae three, Anacardiaceae, Boraginaceae, Myrtaceae and Sapindaceae two, and the remaining families only one. Two samples were monofloral. The predominant pollen types were from Arecaceae (Entre Ríos) and Schinus (Jujuy, Tilquiza) (Fig. 1).

The results obtained with the Monte Carlo Test that perform an exploratory analysis are presented, which show a trend of the association of the variables analyzed.

The samples with the highest $S$. typhi inhibition halo were those from Chaco and Misiones, which had a lower content of phenols. The pollen traces from Chaco honey sample belonged to: Acacia, Aspidosperma quebracho-blanco, Cercidium praecox, Clematis, Fraxinus, Gleditsia amorphoides, Helianthus annus, Peltophorum dubium and Ziziphus mistol species.

Other pollen types related to inhibition were: a) Prosopis, in samples with low inhibition from Jujuy (Palpalá Organic and Santa Bárbara) and Entre Ríos; b) Asteraceae in all the samples studied reaching the secondary category (Misiones) c) Eucalyptus, found in minor frequency class and secondary, in the most inhibited samples Chaco, Misiones, Jujuy (Tilquiza), Jujuy (Palpalá) and Corrientes. Salix was registered in trace also in samples of greater inhibition but in Corrientes sample was found in less importance.

The sample with the highest inhibition of $S$. flexneri halo was that from Corrientes characterized by pollens of: a) Echium and Euphorbiaceae recorded as minor importance; b) Zanthoxylum, Lauraceae and Ilex in traces. Ilex was also present in the Misiones sample. Other pollen types associated with inhibitory capacity are Salix, Solanaceae and Myrtaceae, those that are also present in samples with less inhibition capacity corresponding to Misiones, Chaco, Jujuy (Santa Bárbara), Jujuy (Tilquiza) and Jujuy (Palpalá). The Entre Ríos sample showed an inhibitory capacity related to Arecaceae, registered as dominant.

The highest inhibition of $E$. coli it was observed that the samples from Misiones, Chaco and Corrientes with the lowest content of phenols. The pollen types in Misiones sample were from Lamiaceae and Boraginaceae exclusively, while than in Chaco sample were from Aspidosperma quebracho blanco, Helianthus annuus, Acacia, Cercidium praecox, Peltophorum dubium, Gleditsia amorphoides, Fraxinus, Clematis, Ziziphus mistol. The pollen types in the Corrientes sample were Lauraceae, Echium and Zanthoxylum, Eucalyptus, Prosopis, Baccharis, Asteraceae, Euphorbiaceae and one type identified as Monocotyledonea.

Samples from Jujuy (Palpalá, Palpalá Organic, and Santa Bárbara) had similar inhibitory capacity, but different from the three previous samples, because they had a higher content of phenols. The pollen types of these samples were: Schinus Schinopsis type, Senecio, Serjania, Gomphrena, Sebastiania, Taraxacum officinale, Solanaceae, Myrtaceae, Apiaceae, Poaceae, Bignoniaceae, and Verbenaceae.

The samples from Entre Ríos, Jujuy (Tilquiza) and Jujuy (San Salvador) are those with the least inhibition but with a high content of phenols. In the three analyzes, phenols contents are related to some pollen types such as Arecaceae Schinus, Schinopsis type, Senecio, Fabaceae, Rapistrum rugosum, Eupatorium, Veronica, Bignoniaceae and Rosaceae. The first three were found as dominant or secondary pollen, while the others as less importance or in trace.

\section{Botanical origen of pollens}

From the eight pollen samples analysed, 35 types belonging to 20 botanical families, one subfamily, one class and one undetermined, were identified. Among these families, Fabaceae and Asteraceae presented five and eight types respectively, Myrtaceae and Poaceae two, and the others one pollen type each. According to their frequency class, in three samples were predominant Rapistrum rugosum (Jujuy, Entre Ríos y Misiones), in one Myrtaceae type (Neuquén) and in the other Asteraceae (Tucumán) (Fig. 2).

The samples with the highest inhibition of $S$. typhi were those from Entre Ríos and Neuquén, which are characterized by presenting the highest phenolic content values, followed in order of importance by Santa Fe, Tucumán, Buenos Aires, Misiones, Jujuy and Santiago of Estero. The pollen types were: Caesalpinoideae, exclusive to Entre Ríos; Cardus, in Entre Ríos, Misiones and Buenos Aires samples, and Myrtaceae in Neuquén sample. The lasts three pollen types were a high content of phenols together with Taraxacum officinale and Rapistrum rugosum. The $S$. typhi inhibition by Santa Fe sample (with the lowest phenols content) was associated with Mutisieae, but in Tucumán sample to Ziziphus mistol. Helianthus annus, Amaranthaceae-Chenopodiaceae, Fabaceae and Asteraceae, were present in Santa Fe, Buenos Aires and Tucumán samples.

The greatest inhibition S. flexneri was observed with the Entre Ríos sample, following by that of Buenos Aires. Pollen types that are important in the inhibition of this bacterium, were the same for Salmonella.

The pollen types related to the highest phenols content were: Myrtaceae, in the sample of Neuquén; Taraxacum officinale and Rapistrum rugosum in Neuquén, Jujuy, Entre Ríos, Misiones, Buenos Aires and Santa Fe; Zea mays in Jujuy, Entre Ríos, Misiones. 

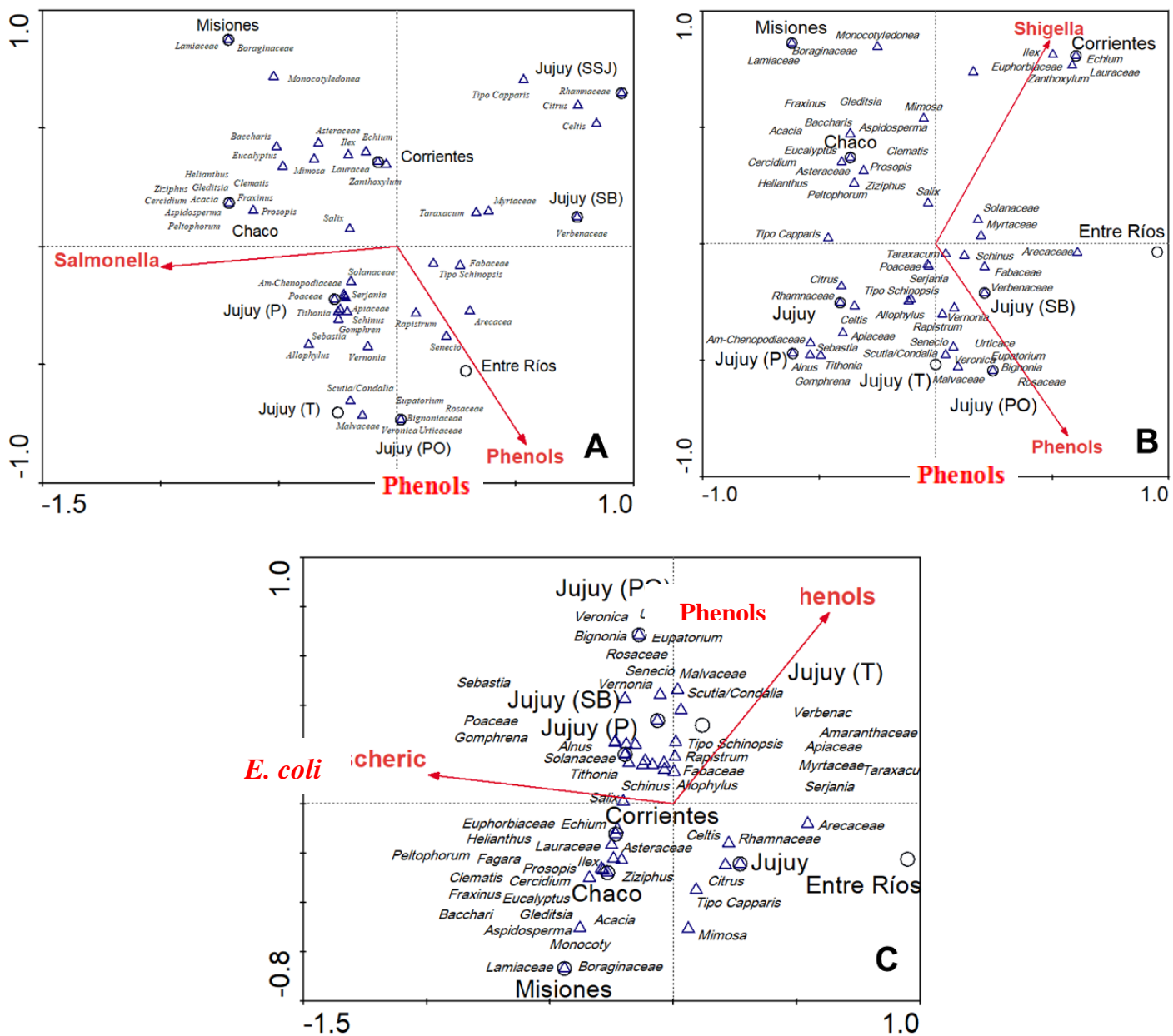

Figure 1 Samples of honey. CCA plot showing the relationship between the content of phenols and the inhibition of bacteria: A. Salmonella; B. Shigella; C. Escherichia coli.
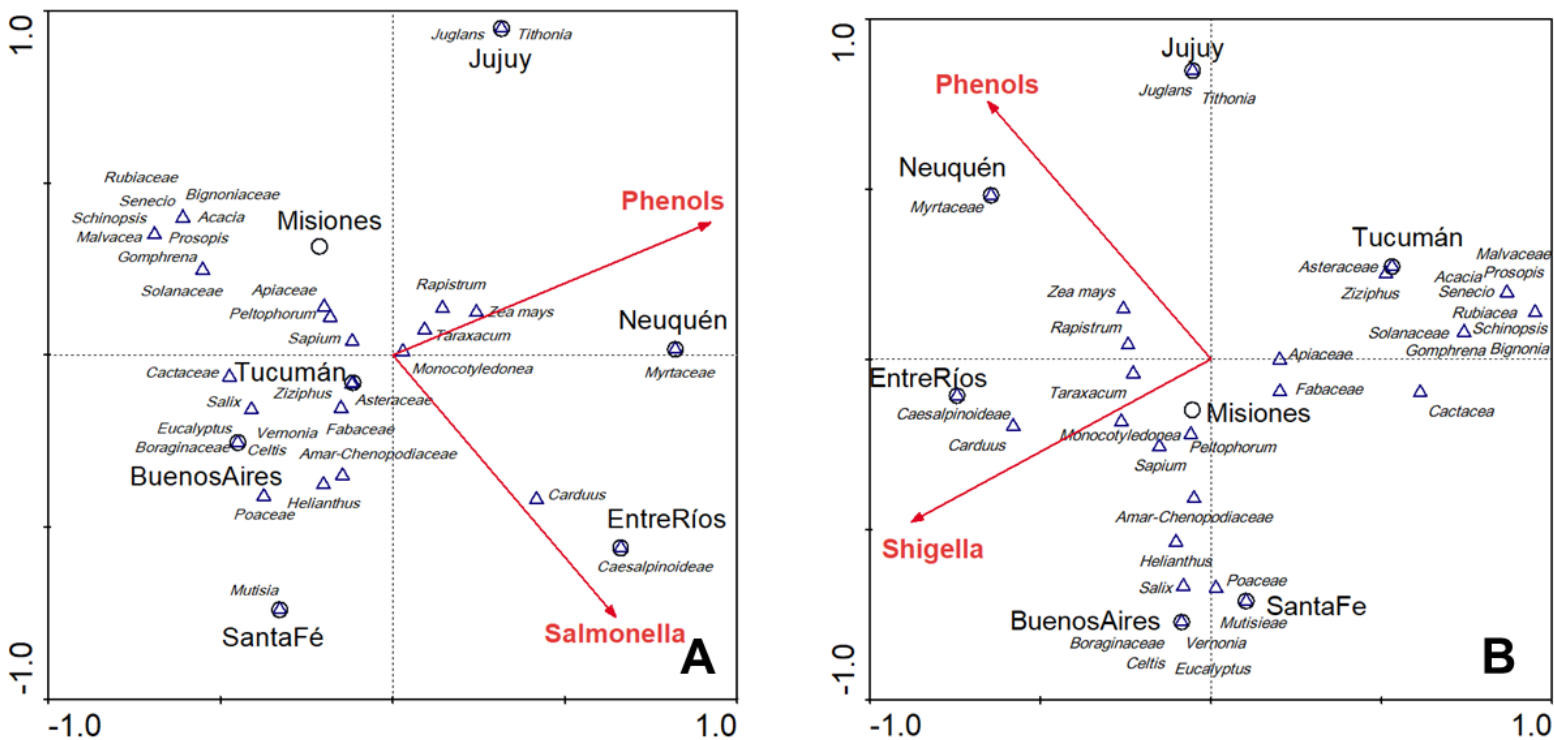

Figure 2 Samples of pollen. CCA plot showing the relationship between the content of phenols and the inhibition of bacteria: A. Salmonella; B. Shigella.

\section{DISCUSSION}

The antimicrobial activity of honey depends on several factors which function singularly or synergistically, related to hydrogen of peroxide, phenolic compounds, low $\mathrm{pH}$, osmotic pressure and other phytochemicals contents (Mandal and Mandal, 2011). Honey has the ability to generate hydrogen peroxide related to antimicrobial activity. The production of hydrogen peroxide is due to the transformation of glucose acting as substrate for glucose oxidase enzyme present in honey, which concentration depends on the floral origin (Jantakee and Tragoolpua, 2015), which is related to the results of this study where differences in the inhibitory capacity of the different provinces were shown due to different floral origins, since in this work it resulted in lower phenolic contents than pollens.

The greatest inhibition halos were produced by honey from Corrientes and pollen from Misiones indicating that Apis mellifera L. uses different floral sources for the production of honey, which explains the difference in their antibacterial 
effect, that at the same time its effect could be due to the pollen types found as Eucalyptus and Laurel (Ewnetu et al., 2013; Montero-Recalde et al., 2019). Shown inhibition halos are higher than those proposed in other studies indicating that honeys from Argentina have a greater inhibitory effect (Fatrcová-Šramková et al., 2013). Other studies have shown, the action of the compounds of honey, in bacteria, they act on the cell wall (murein/peptidoglycan) in E. coli inducing perturbations in its integrity, many of these effects are due to active anti-bacteria proteins, including the glycoproteins resistant to diseases found in plants, this would allow them to recognize and bind bacterial cells, affecting their growth, survival and other mechanisms (Brudzynski et al., 2015).

Polyphenols are able to inhibit microorganisms and antimicrobial activity is dependent on their chemical structure and environmental conditions. The effect of flavonoids and phenolic acids present in pollen cause interruption of bacterial metabolism. The mechanism consists of the formation of complexes with the cell wall by exposure on the surface of adhesins and polypeptides, and/or cell membrane enzymes, which leads to interruption of the integrity of the cell wall, block of ion channels, and inhibition of the flow of electrons from the transport chain by scanning electron (Rzepecka-Stojko et al., 2015).

Therefore, antibacterial activity of the different varieties of honey is due to the activity of the hydrogen peroxide. This would generate free hydroxyl radicals which break DNA and oxidize thiol groups of proteins and lipids, causing damage of the bacterial cells (Jantakee and Tragoolpua, 2015).

This work coincides with Fatrcová-Sramkova (Fatrcová-Šramková et al., 2013), and would demonstrate that the effect of pollen is due to the concentration of phenols in the sample and not the effect of honey that might be related to proteins similar to those found in plants that are resistant to diseases (Brudzynski and Sjaarda, 2015) and/or the concentration of the enzyme glucose oxidase from different plants associated to regions.

The high resistance values obtained by Adefisoye (Adefisoye and Okoh, 2016) may suggest exposure to bacterial antibiotics isolated, this could be due to improper use of antibiotics among the population, and can lead to increase the development of multi-drug resistance. They have identified genes that confer resistance mainly to tetracycline and ampicillin (Adefisoye and Okoh, 2016, Lalak et al., 2016)

\section{CONCLUSION}

In this study it was found the antimicrobial effect of pollen and honey against $S$ flexneri, E. coli and S. typhi enteropathogenic, were superior to those shown by commercial antibiotics. Honeys showed greater inhibitory effect than pollens. The effect shown by pollens could be attributed to the phenols concentration.

Acknowledgements: The authors appreciate the financial support of SECTER, from the National University of Jujuy. Tejerina Marcos Raúl has a postdoctora studies fellowship from Consejo Nacional de Investigaciones Científicas y Técnicas (CONICET-Argentina).

\section{REFERENCES}

Adefisoye, M.A., Okoh, A.I. (2016). Identification and antimicrobial resistance prevalence of pathogenic Escherichia coli strains from treated wastewater effluents in Eastern Cape, South Africa. Microbiology Open; 5(1): 143-151. https://doi.org/10.1002/mbo3.319

Bauer, A.W., Kirby, W.M.M., Sherris, J.C., Turck, M. (1966). Antibiotic susceptibility testing by a standardized single disk method. Am J Clin Pathol.; 45: 493-496. https://doi.org/10.1093/ajcp/45.4_ts.493

Brudzynski, K., Sjaarda, C. (2015). Honey Glycoproteins Containing Antimicrobial Peptides, Jelleins of the Major Royal Jelly Protein 1, Are Responsible for the Cell WallLytic and Bactericidal Activities of Honey. PLoS ONE; 10(4): e0120238. https://doi.org/10.1371/journal.pone.0120238

Cabrera, C., Montenegro, G. (2013). Pathogen control using a natural Chilean bee pollen extract of known botanical origin. Cienc. Inv. Agr.; 40 (1):223-230. https://doi.org/10.4067/s0718-16202013000100020

De Toro, M., Seral C, Rojo-Bezares, B., Torres, C, Castillo, F.J., Sáenz, Y. (2014). Antibiotic resistance and virulence factors in clinical Salmonella enterica isolates. Enferm. Infecc. Microbiol. Clin.; 32(1):4-10. https://doi.org/10.1016/j.eimc.2013.03.006

Della Gaspera, A, M.I., Caffe, M. P., Vinas, M.R., Hebe, A., Barrios, S.S., Viora R.J.A. (2015). Brote de shigelosis en la ciudad de Luján, Argentina. Rev. Argent Microbiol. 26(2): 1-6. https://doi.org/10.1016/j.ram.2015.02.003

Di Rienzo, J.A., Casanoves, F., Balzanini, M.G., Gonzalez, L., Tablada, M. Robledo, C.W., (2008). Grupo Infostat, versión 2008, FCA, Univ. Nacional de Córdoba, Argentina. http://www.infostat.com.ar

Erdtman, G. (1960). The acetolysis method, a revised description. Svensk. Bot Tidskr. 54: 561-564. https://doi.org/10.1080/00173136009429446

Ewnetu, Y., Wossenseged, L., Birhane, N. (2013) Antibacterial effects of Apis mellifera and stingless bee honeys on susceptible and resistant strains of Escherichia coli, Staphylococcus aureus and Klebsiella pneumoniae in Gondar, Northwest Ethiopia. BMC Complementary and Alternative Medicine; 13: 269. https://doi.org/10.1186/1472-6882-13-269
Fatrcová-Šramková, K., Nôžková, J., Kačániová, M., Máriássyová, M., Rovná, K., Stričík, M.( 2013). Antioxidant and antimicrobial properties of monofloral bee pollen. Journal of Environmental Science and Health, Part B: Pesticides, Food Contaminants, and Agricultural Wastes; 48(2): 133-138 https://doi.org/10.1080/03601234.2013.727664

Jantakee, K., Tragoolpua, Y. (2015). Activities of different types of Thai honey on pathogenic bacteria causing skin diseases, tyrosinase enzyme and generating free radicals. Biological Research, 48(1). https://doi.org/10.1186/0717-6287-48-4 Kwakman, P.H., Te Velde, A.A., Boer, L., Speijer, D., Vandenbroucke-Grauls, C.M., Zaat, S.A. (2010). How honey kills bacteria. Faseb J.; 24(7): 2576 - 2582 https://doi.org/10.1096/fj.09-150789

Lalak, A., Wasyl, D., Zaja, M., Skarzynska, M., Hoszowski, A., Samcik, I., Wonzniakowski, G., Szulowski, K. (2016). Mechanisms of cephalosporin resistance in indicator Escherichia coli isolated from food animals. Vet. Microbiol. 194: 69-73. https://doi.org/10.1016/j.vetmic.2016.01.023

Leps, J. and Smilauer, P. (2003). Multivariate Analysis of Ecological Data Using CANOCO. Cambridge University Press, Cambridge. https://doi.org/10.1017/cbo9780511615146.005

Libonatti, C., Soledad, V., \& Marina, B. (2014). Antibacterial activity of honey: A review of honey around the world. Journal of Microbiology and Antimicrobials, 6(3), 51-56. https://doi.org/10.5897/jma2014.0308

Louveaux J., Maurizio A., Vorwhol G. (1970). Methods of melisso-palynology by International Commission of Bee Botany of IUBS. Bee World 59: 139-157. https://doi.org/10.1080/0005772x.1970.11097312

Mandal, M.D., \& Mandal, S. (2011). Honey: its medicinal property and antibacterial activity. Asian Pacific journal of tropical biomedicine, 1(2): 154 160. https://doi.org/10.1016/s2221-1691(11)60016-6

Montero-Recalde, M., Morocho-Núñez, M.J., Avilés-Esquivel, D., CarrascoCando, Á., \& Erazo-Gutierrez, R.. (2019). Eficacia antimicrobiana del aceite esencial de eucalipto (Eucalyptus spp) sobre cepas de Escherichia coli y Staphylococcus aureus subsp. aureus. Revista de Investigaciones Veterinarias del Perú, 30(2): 932-938. https://doi.org/10.15381/rivep.v30i2.16099

Rosenblatt-Farrell, N. (2009). El paisaje de la resistencia a los antibióticos. Environmental Health Perspectives. $117 \quad$ (6): 244-250. https://doi.org/10.1590/s0036-36342009000500011

Ruíz, J., Ramallo, M.G., Rocío, Colello R.,VhIalobo, C., Monteavaro, C. Etcheverría, A., Padola, N.L. (2018). Diferentes métodos para aislamiento y detección de Salmonella spp. en canales porcinas. Revista Colombiana de Biotecnología 20(2):

https://doi.org/10.15446/rev.colomb.biote.v20n2.71680

Rzepecka-Stojko, A., Stojko, J, Kurek-Górecka, A., Górecki, M., Kabała-Dzik, A., Kubina, R., Moździerz, A., Buszman, E. (2015). Polyphenols from bee pollen: structure, absorption, metabolism and biological activity. Molecules 2015; 20

https://doi.org/10.3390/molecules201219800

Saurabh, A., Sarkar, P., Saha, D.R., Patra, A., Ramamurthy, T., Prasanta, K. (2015). Intracellular and membrane-damaging activities of methyl gallete isolated from Terminalia chebula against multidrug-resistant Shigella spp. J Med Microbiol.; 64 (8): 901-909. https://doi.org/10.1099/jmm.0.000107

Töpfer G. 2018. Folin-Ciocalteu-Methode. In: Gressner A., Arndt T. (eds) Lexikon der Medizinischen Laboratoriumsdiagnostik. Springer Reference Medizin. Springer, Berlin, Heidelberg. https://doi.org/10.1007/978-3-662-490549_1157-1 